\title{
METODE DISKUSI BERBASIS LEARNING MANAGEMENT SYSTEM (LMS) UNTUK MENINGKATKAN KEMAMPUAN BERPIKIR KRITIS MAHASISWA
}

\author{
Hikmawati ${ }^{1}$, Haerunisyah Sahidu ${ }^{1)}$, Kosim $^{1)}$ \\ 1)Program Studi Pendidikan Fisika, FKIP, Universitas Mataram, Mataram, NTB, Indonesia \\ Corresponding author : Hikmawati \\ E-mail : hikmawati@unram.ac.id
}

Diterima 30 Oktober 2020, Direvisi 30 November 2020, Disetujui 21 Desember 2020

\begin{abstract}
ABSTRAK
Penelitian ini bertujuan untuk mendeskripsikan implementasi metode diskusi berbasis Learning Management System (LMS) untuk meningkatkan kemampuan berpikir kritis mahasiswa. Jenis penelitian ini adalah pre-experimental dengan one-group pretest-posttest design. Subjek penelitian ini adalah mahasiswa di Kelas IVIA yang mengambil mata kuliah Strategi Pembelajaran Fisika pada Program Studi Pendidikan Fisika, FKIP Universitas Mataram, Semester Genap Tahun Pelajaran 2019/2020 sebanyak 19 orang. Instrumen yang digunakan dalam penelitian ini adalah lembar observasi implementasi metode diskusi berbasis LMS dan tes kemampuan berpikir kritis mahasiswa. Hasil penelitian menunjukkan bahwa: (1) persentase implementasi metode diskusi berbasis LMS meningkat, dari $75 \%$ menjadi $92 \%$, yang berarti kualitas pembelajaran yang lebih baik, dan (2) kemampuan berpikir kritis mahasiswa meningkat dari 54 menjadi 82 dengan ketuntasan klasikal $5 \%$ menjadi $89 \%$. Nilai rata-rata $\mathrm{N}$-gain sebesar 60 dengan kriteria sedang. Disimpulkan bahwa metode diskusi berbasis Learning Management System (LMS) dapat meningkatkan kemampuan berpikir kritis mahasiswa pada perkuliahan Strategi Pembelajaran Fisika.
\end{abstract}

Kata kunci: diskusi; LMS; kemampuan berpikir kritis.

\begin{abstract}
This study aims to describe the implementation of the Learning Management System (LMS) based discussion method to improve students' critical thinking skills. This research type is pre-experimental with one-group pretest-posttest design. The subjects of this research were 19 students in Class IV / A who took the Physics Learning Strategy course at the Physics Education Study Program, FKIP University of Mataram, even semester of the 2019/2020 academic year. The instrument used in this study was the observation sheet on the implementation of the LMS-based discussion method and the test of students' critical thinking skills. The results showed that: (1) the percentage of LMS-based discussion method implementation increased, from $75 \%$ to $92 \%$, which means better learning quality, and (2) students' critical thinking skills increased from 54 to 82 with classical completeness of $5 \%$ to $89 \%$. The average $\mathrm{N}$-gain value is 60 with moderate criteria. It is concluded that the Learning Management System (LMS) based discussion method can improve students' critical thinking skills in Physics Learning Strategies lectures.
\end{abstract}

Keywords: discussion; LMS; critical thinking skills.

\section{PENDAHULUAN}

Berpikir kritis merupakan pemikiran yang berbeda dicirikan oleh analisis dan pengambilan keputusan yang hati-hati (Copper \& Patton, 2004). Kemampuan berpikir kritis merupakan salah satu kompetensi yang harus dimiliki mahasiswa di abad ke-21. Menurut Fridanianti, dkk (2018), empat kompetensi yang harus dimiliki siswa di abad 21 disebut $4 \mathrm{C}$, yaitu berpikir kritis dan menyelesaikan masalah (Critical Thinking and Problem Solving), kreativitas (Creativity), kemampuan berkomunikasi (Communication Skills), dan kemampuan untuk bekerja sama (Ability to Work Collaboratively).

Untuk meningkatkan kemampuan berpikir kritis diperlukan metode pembelajaran yang dapat memfasilitasi mahasiswa untuk memecahkan masalah sehingga mereka dapat melakukan analisis dan mengambil keputusan, seperti metode diskusi. Metode diskusi memungkinkan mahasiswa berkomunikasi tentang materi pelajaran dengan mahasiswa lain maupun dengan dosen (Suprihatiningrum, 2013).

Metode diskusi dapat dilakukan dalam pembelajaran luring di kelas maupun daring 
melalui LMS. Menurut Junaedi, dkk, (2020), sistem pengelolaan pembelajaran/ Learning Management System (LMS) merupakan sebuah sistem yang digunakan untuk melakukan proses pembelajaran dengan memanfaatkan Teknologi Informasi dan Komunikasi (TIK) dan merupakan hasil integrasi secara sistematis atas komponenkomponen pembelajaran dengan memperhatikan mutu, sumber belajar, dan berciri khas adanya interaksi pembelajaran (engagement) lintas waktu dan ruang. Tujuan penting dari LMS tersebut adalah memberikan akses dan fasilitas kepada peserta didik untuk membangun pengetahuannya secara mandiri dan terarah, serta memberikan peran penting dosen sebagai perancang, pemantik, fasilitator, dan motivator pembelajaran.

Tujuan penelitian ini adalah untuk mendeskripsikan implementasi metode diskusi berbasis Learning Management System (LMS) untuk meningkatkan kemampuan berpikir kritis mahasiswa.

\section{METODE PENELITIAN}

Jenis penelitian termasuk dalam preeksperimental dengan desain penelitian yang digunakan adalah One Group Pre-test dan Post-test Design (Arikunto, 2006). Subjek penelitian ini adalah mahasiswa di Kelas IVIA yang mengambil mata kuliah Strategi Pembelajaran Fisika pada Program Studi Pendidikan Fisika, FKIP Universitas Mataram, Semester Genap Tahun Pelajaran 2019/2020 sebanyak 19 orang.

Persentase implementasi metode diskusi berbasis Learning Management System (LMS) diperoleh dengan membagi jumlah aspek yang diterapkan dalam pembelajaran dengan total aspek dikalikan $100 \%$. Instrumen tes kemampuan berpikir kritis berbentuk tes essay. Kemampuan berpikir kritis yang dinilai terdiri dari 6 komponen yaitu merumuskan masalah, memberikan argumen, melakukan deduksi, melakukan induksi, melakukan evaluasi, mengambil keputusan (Ramdani, 2020). Skor penilaian setiap komponen menggunakan skala 4 (Kemendikbud, 2013), sedangkan nilai persentase diperoleh melalui skor mentah dibagi skor maksimum dikali 100 (Purwanto, 2004). Analisis ketuntasan belajar klasikal mahasiswa dinyatakan dalam bentuk persentase yaitu apabila $80 \%$ memperoleh nilai minimal 72.

Tabel 1. Kriteria Kemampuan Berpikir Kritis

\begin{tabular}{ll}
\hline Skor & Kriteria \\
\hline $3,50-4,00$ & Sangat Kritis \\
$3,00-3,49$ & Kritis \\
$2,00-2,99$ & Kurang Kritis \\
$1,00-1,99$ & Tidak Kritis \\
\hline
\end{tabular}

Peningkatan skor dihitung menggunakan $\mathrm{N}$-gain (Hake, 1999) dengan menggunakan rumus:

$$
\mathrm{N}-\text { gain }=\frac{\mathrm{S}_{\text {post }}-\mathrm{S}_{\text {pre }}}{\mathrm{S}_{\text {max }}-\mathrm{S}_{\text {pre }}} \times 100 \%
$$

Kategori perolehan $\mathrm{N}$-gain adalah seperti yang disajikan pada Tabel 2 berikut.

Tabel 2. Kriteria Perolehan N-gain

\begin{tabular}{lll}
\hline No. & Interval $(\%)$ & Kriteria \\
\hline 1 & $\mathrm{~g}>70$ & Tinggi \\
2 & $30 \leq \mathrm{g} \leq 70$ & Sedang \\
3 & $\mathrm{~g}<30$ & Rendah \\
\hline
\end{tabular}

\section{HASIL DAN PEMBAHASAN}

Nilai keterlaksanaan pembelajaran dengan metode diskusi berbasis LMS adalah sebagai berikut.

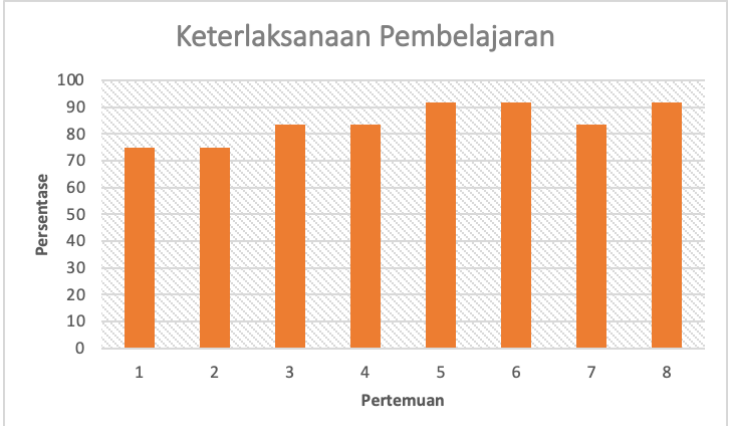

Gambar 1. Keterlaksanaan Pembelajaran

Aspek yang diamati pada keterlaksanaan pembelajaran terdiri atas pendahuluan, kegiatan inti, dan penutup. Implementasi metode diskusi berbasis LMS ini dilaksanakan selama 8 kali pertemuan. Persentase nilai rata-rata keterlaksanaan pembelajaran adalah sebesar $84 \%$. Persentase implementasi metode diskusi berbasis LMS pada pertemuan 1 sebesar $75 \%$ meningkat menjadi $92 \%$ pada pertemuan 8 , yang berarti kualitas pembelajaran yang lebih baik.

Nilai tiap komponen dalam kemampuan berpikir kritis dapat dilihat pada Gambar 2.

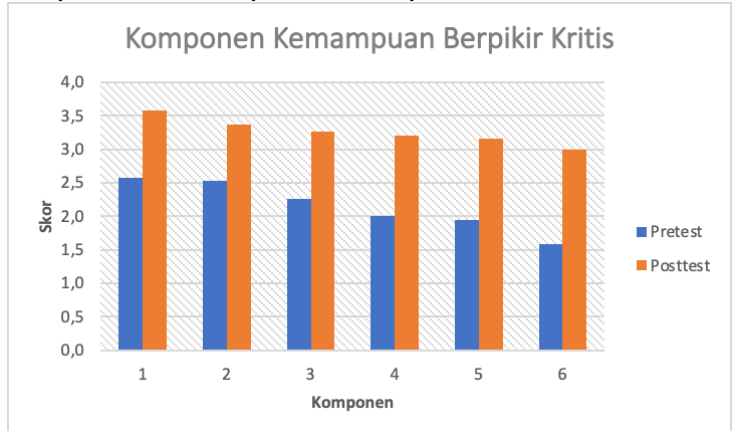

Gambar 2. Nilai setiap komponen kemampuan berpikir kritis 
Nilai rata-rata komponen kemampuan berpikir kritis pada saat pretest adalah sebesar 2,15 (kriteria kurang kritis) naik menjadi 3,26 (kriteria kritis) pada saat posttest. Menurut Ramdani (2020), komponen pertama, merumuskan masalah, memiliki indikator yaitu: memformulasikan dalam bentuk pertanyaan yang memberi arah untuk memperoleh jawabannya. Komponen kedua, memberikan argumen, memiliki indikator yaitu: argument dengan alasan yang sesuai; menunjukkan perbedaan dan persamaan; argumennya utuh. Komponen ketiga, melakukan deduksi, memiliki indikator yaitu: mendeduksi secara logis; kondisi logis; melakukan interpretasi terhadap pernyataan. Komponen keempat, melakukan induksi, memiliki indikator yaitu: melakukan investigasi/pengumpulan data; membuat generalisasi dari data, membuat tabel, dan grafik; membuat simpulan terkait hipotesis; memberikan asumsi yang logis. Komponen kelima, melakukan evaluasi, memiliki indikator yaitu: evaluasi dilakukan berdasarkan fakta; berdasarkan prinsip atau pedoman; memberikan alternatif. Komponen keenam, mengambil keputusan, memiliki indikator yaitu: memilih kemungkinan solusi; menentukan kemungkinan-kemungkinan yang akan dilaksanakan.

Nilai kemampuan berpikir kritis mahasiswa dapat dilihat pada Gambar 3 berikut.

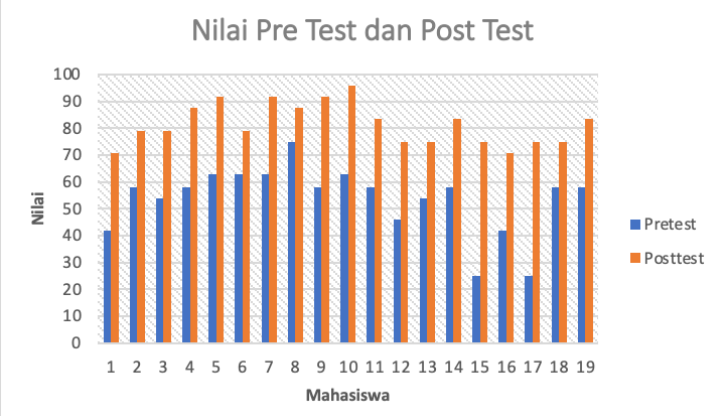

Gambar 3. Nilai kemampuan berpikir tingkat tinggi mahasiswa

Nilai rata-rata kemampuan berpikir kritis mahasiswa pada saat pretest adalah sebesar 54, sedangkan pada saat post test adalah sebesar 82 , sehingga nilai rata-rata $\mathrm{N}$ gain adalah sebesar 60 dengan kriteria sedang, Adapun ketuntasan belajar klasikal mahasiswa naik dari $5 \%$ menjadi $89 \%$. Mahasiswa yang berpikir kritis mampu menginterpretasi, menganalisis, menjelaskan, dan menyimpulkan (Hapsari, 2016). Berpikir kritis memainkan peran penting bagi mahasiswa dalam memecahkan masalah (Fitriana, 2018). Kemampuan berpikir kritis sangat penting dimiliki oleh setiap individu karena dengan berpikir kritis seseorang akan lebih bijak dalam menghadapi segala kejadian dalam kehidupannya (Rohmatin, 2012).

\section{SIMPULAN DAN SARAN}

Kesimpulan dari penelitian ini adalah metode diskusi berbasis Learning Management System (LMS) dapat meningkatkan kemampuan berpikir kritis mahasiswa pada perkuliahan Strategi Pembelajaran Fisika.

Saran yang dapat peneliti kemukakan adalah metode diskusi berbasis LMS dapat menjadi alternatif metode yang dapat digunakan dalam perkuliahan berbasis daring.

\section{DAFTAR RUJUKAN}

Arikunto, Suharsimi. (2006). Prosedur Penelitian: Suatu Pendekatan Praktik. Jakarta: Rineka Cipta.

Copper, S \& Patton, R. (2004). Writing Logically, Thinking Critically. New York: Pearson Longman.

Fitriana, LD., Fuad, Y, Ekawati, R. (2018). Student's Critical Thinking in Solving Open-Ended Problems Based on Their Personality Type. J. Phys.: Conf. Ser. 947012007.

Fridanianti, A., Purwati, H., Murtianto, YH. (2018). Analisis Kemampuan Berpikir Kritis Dalam Menyelesaikan Soal Aljabar Kelas VII SMP Negeri 2 Pangkah Ditinjau dari Gaya Kognitif Reflektif dan Kognitif Impulsif. Aksioma, Vol. 9, No. 1, 11-20.

Hake, R. (1999). Analyzing Change/ Gain Score. Indiana: Indiana University.

Hapsari S. (2016). A Descriptive Atudy of The Critical Thinking Skills of Social Science Junior High School. Journal of Education and Learning. Vol.10 (3) pp. 228-234.

Junaedi, A., dkk. (2020). Panduan Penyusunan Kurikulum Pendidikan Tinggi di Era Industri 4.0 untuk Mendukung Merdeka Belajar-Kampus Merdeka. Jakarta: Dirjen Dikti, Kemendikbud.

Kemendikbud. (2013). Materi Pelatihan Guru: Implementasi Kurikulum 2013. Jakarta: Kemendikbud.

Purwanto, M., N. (2004). Prinsip-Prinsip dan Teknik Evaluasi Pengajaran. Bandung: Remaja Rosdakarya.

Ramdani, Agus. (2020). Pengembangan Perangkat Pembelajaran Inkuiri Melalui Kegiatan Lesson Study. Mataram: Mataram University Press.

Rohmatin, DN. (2012). Profil Berpikir Kritis Siswa SMP Dalam Memecahkan Masalah Geometri Ditinjau Dari Tingkat IQ. Gamatika Vol. III No.1, 1-9. 
Suprihatiningrum, J. (2013). Strategi Pembelajaran. Jogjakarta: Ar-Ruzz Media. 